\title{
ARTICLE
}

\section{What are case studies good for? Nesting Comparative Case Study Research into the Lakatosian Research Program}

\author{
Matia Vannoni, School of Public Policy, University College London, The Rubin Building, \\ 29/31 Tavistock Square, London, WC1H 9QU, UK \\ Email:m.vannoni.12@ucl.ac.uk
}

\begin{abstract}
This article discusses two of the most used methods of comparative case study research, namely John Stuart Mill's (Millian) method of agreement and the method of difference. In doing so, it claims that those methods allow social research to progress theoretically and empirically if the latter is assessed through the epistemological framework of the research program. The latter represents a series of guidelines to assay the progress of science provided by Imre Lakatos' philosophy of science. In fact, those two methods can be employed according to two methodologies, namely concept formation and causal inference, which in turn perform specific functions essential for social research to develop theoretically and empirically in line with the guidelines established by the research program. In conclusion, a more nuanced discussion of the link between epistemology, methodology and methods is needed to fully appreciate what comparative case study research is good for.
\end{abstract}

\section{Keywords}

Qualitative research, philosophy of science, methodology, research program, Lakatos, comparative research, case study, Mill 


\section{Introduction}

By building on the concept of research program I posit that the John Stuart Mill (Millian) method of agreement and the method of difference perform complementary functions which allow research to progress both theoretically and empirically. The research program, as put forward in Imre Lakatos' philosophy of science, presents a series of guidelines to assay the development of research in a field: a new theory should be more explanatorily powerful as well as empirically tested. If used in conjunction the Millian methods can derive a new theory which explains novel facts, through their concept formation methodology, and they can provide an empirical test for that new theory, through their inferential methodology.

This work provides a threefold contribution. First of all, it contextualises comparative case study research into a broader discussion on the philosophy of science. In doing so, it links epistemology, methodology and methods within a single framework. By starting from two methods, namely the Millian comparative methods, I demonstrate that thanks to their two methodologies, namely concept formation and causal inference, they allow research to progress according to epistemological rules, namely the ones provided by the research program. Secondly, this work provides an intuitive template to conduct case study research in an epistemologically and methodologically sound as well as effective and efficient manner. Indeed, as shown in the example below, the combination of the two methods discussed in this work usually does not usually require more than the description of four instances of different phenomena occurring in the same period and country. Last but not least, this work paves the way for a more nuanced discussion on the role of case study research and more generally qualitative research in social sciences. In fact, it demonstrates how theoretical and empirical progress can be achieved through comparative case study research without any support from statistical analysis, for instance.

This work commences by introducing the concepts of case, sample and population and by claiming that comparative case study research embodies two methodologies which cannot and should not be disentangled: concept formation and causal inference. Then, the two most common ways to compare cases, namely the Millian method of agreement (in this work called the MA method) and the method of difference (in this work called the MD method), are discussed with special emphasis on their comparative advantages and disadvantages. This work proceeds to the introduction of Lakatos' research program as a way in which research (should) evolves and the ensuing section demonstrates how theoretical and empirical progress can be achieved by using the two Millian methods as both concept formation and inferential tools. In this vein, this work connects epistemology, methodology and methods. Then, an example of research program in social research, namely the political economy of 
redistribution, is provided for illustrative purposes. The last section concludes by illustrating the application of comparative case study research in another field of study which can be assayed as a research program, namely the political economy of corporate governance. Several conclusions are drawn, some of which purposely more provocative than substantiated in order to open a discussion in the field on the topics dealt with in this work.

\section{Comparative Case Study Research}

A case is a spatially and temporally bounded political and/or social space and, as emphasised below, the spatial and temporal boundaries are determined according to the theory the researcher addresses. Similar cases (again, similar with respect to the theory) form a population for which the researcher aims to infer causal relationships by extracting a sample. Cases in turn are divided into variables or factors for which observations are collected (Gerring, 2004). Comparative case study on its part is a qualitative research method which aims to infer causal relationships between factors by systematically comparing instances of a phenomenon, namely cases conceived as different configurations of variables or factors (Rihoux \& Ragin, 2009). As argued by some authors (Mahoney, 2007; Ragin, 2010) comparative research bears also on the function of concept formation. I posit that the inferential and the concept formation functions cannot be disentangled, as instead argued by Lijphart (1971) and Schwartz-Shea and Yanow (2002): in the comparative method these two functions can and must be reconciled (Mahoney, 2007; George and Bennett, 2005) $)^{i}$. Another criterion defining comparative research is the number of instances under analysis which is inferior to those analysed with statistical methods. Yet, no left cut-point is needed to define comparative case study research. In fact, what are labelled as single case studies, such as deviant and limiting cases (Gerring, 2007b) are often nothing more than comparative research conducted in an implicit (Lijphart, 1971) or introverted (Rose, 1991) mannerii. They, indeed, compare the case under analysis with the hypothetical population of cases to which the theory at stake applies with inferential purposes.

\section{The Millian Comparative Methods}

Although by using different labels when comparing cases to infer causal relations scholars have mostly used the method of difference and the method of agreement ${ }^{i i i}$. The logical foundation of those two methods may be traced back to Mill's (1888) masterpiece, where he identifies two methods of elimination of potential explanations related to a phenomenon ${ }^{\text {iv }}$. In inquiring the potential cause of an effect (or the other way round) two methods may be employed: either the researcher compares cases as similar as possible or as different as possible except for the dimensions in which he/she is interested. As rightly emphasised by Rihoux and Ragin (2009), a fruitful discussion on these two methods must take into 
consideration both the dimensions, on which the discussion by Przeworski and Teune (1970) primarily centres, and the outcomes of cases, which receives more emphasis in Mill's (1888) discussion. In this vein, the two methods may be also labelled most different and similar outcome (the MA method) and most similar and different outcome (the MD method) (Rihoux \& Ragin, 2009). The MA method compares two (or more) cases as different as possible with the exception of the dependent and the independent variables whilst the MD method compares similar cases with the exception of the dependent and the independent variables. In the former the researcher proceeds by eliminating the differences between the two cases as potential explanations whereas in the latter he/she eliminates the similarities.

The literature has always been sceptical in employing those methods in social sciences. The major reason being the comparability of cases, namely that the possibility of finding two most similar or different cases in social reality is arguably really low (Mill, 1888; Skocpol \& Somers, 1980). Indeed, ideally the MD and the MA methods should compare respectively two identical or completely different cases apart from the independent and dependent variable. Furthermore, scholars have also emphasised the idiosyncrasies of each method: equifinality, with the risk of failing to reject a false null hypothesis, and overdetermination, with the risk of falsely rejecting a true null hypothesis, are deemed to plague respectively the MA method (Mill, 1888) and the MD method (Gerring, 2004; Odell, 2001; Przeworski \& Teune, 1970) ${ }^{v}$. Equifinality refers to different configurations of variables or factors associated with the same outcome. The selection on the dependent variable typical of the MA method (Geddes, 1990; King, Keohane, \& Verba, 1994) does not allow the researcher to exclude other potential configurations which lead to the same outcome. Figure 1 builds on the discussion in Geddes (1990) and it illustrates the issue of equifinality when using the MA method. Equifinality in this example refers to the fact that two configurations of variables, namely $X_{1}, X_{2}$ and $X_{3}$ and $X_{0}, X_{2}$ and $X_{3}$, are associated with the same outcome, namely $Y$. By comparing the cases $A$ and $B$ with the MA method the researcher cannot reject the false null hypothesis in the bottom right panel $\mathrm{l}^{\mathrm{vi}}$. In other words, by employing exclusively the MA method the researcher cannot infer a relationship between $\mathrm{X}_{1}$ and $\mathrm{Y}$.

\section{(Figure 1)}

The literature has hitherto agreed that the low degrees of freedom associated with the MD method does not allow the researcher to control for all the factors present in the analysis (Lijphart, 1971). The problem of too many variables and too few cases has been identified by the literature as the most serious one in comparative case study research (King et al., 1994). Figure 2 illustrates the issue of overdetermination in the MD method: in this example the 
researcher analyses the relationship between two variables in two cases. In this case the researcher cannot conclude that $\mathrm{IV}_{1}$ is related to $\mathrm{DV}$, let alone infer causality. Indeed, a relationship is present also between DV and $\mathrm{IV}_{0}$, as shown in the bottom left panel. In this vein, the researcher cannot infer a causal relationship between $\mathrm{IV}_{1}$ and $\mathrm{DV}$ in that unable to reject the true null hypothesis that $\mathrm{IV}_{0}$ is related to DV. The researcher does not know whether the relationship between IV $\mathrm{V}_{1}$ and $\mathrm{DV}$ is spurious and, relatedly, whether and how IV and $\mathrm{IV}_{0}$ are associated. The traditional methodology literature (King et al., 1994; Lijphart, 1971) has hitherto proposed the increase in sample size as the main solution to this problem, namely by adding a case $\mathrm{C}$ to control for $\mathrm{X}_{0}$.

\section{(Figure 2)}

The two methods receive separate attention also for what concerns their comparative advantages: the literature focuses on the claims the two methods give rise to and on the type of variance which they account for. First of all, the MD method is considered to formulate in-depth claims about social reality with high internal validity whereas the MA generates claims with high external validity (Rihoux \& Ragin, 2009). As claimed by Przeworski and Teune (1970), by excluding all the differences between cases the MA method allows the researcher to move the focus of the analysis, from the reforms of the market of corporate control in Germany and France to the power of organised business in corporate governance reform in the example provided below, and thus to draw more generalizable conclusions. Conversely, in the MD the focus of the analysis remains the same, namely the reform of the market of corporate control in the example, thus providing a more detailed description of the phenomenon under analysis in different contexts but less generalizable results. This is thoroughly discussed in the example below.

Not only do the two methods differ with respect to the scope of the claims the researcher derives from them, but they also differ with respect to their content. As emphasised by Mill (1888), the method of difference inquiries the cause of an effect thus identifying necessary conditions whereas the method of agreement investigates the outcome of a cause thus looking for sufficient conditions (Ragin, 2010). Indeed, the MD method usually starts from an unexpected difference in the outcome between two similar cases thus leading the researcher to inquiry into the cause of that outcome (Hancké, 2009). In this vein, the MD method allows the researcher to state that the independent variable is a necessary condition for the dependent one in that they co-vary (Skocpol, 1984). The MD method compares a configuration where the independent and dependent variables are present with a configuration where they are not. In Goertz and Levy's (2007) words, the researcher needs 
counterfactuals in order to identify necessary causes. Contrariwise, the MA method allows the researcher to look for the sufficient conditions for an outcome. Indeed, the cases under analysis in the MA method present configurations where the independent and dependent variables of interest are present ${ }^{\mathrm{vii}}$. As for the type of variation under analysis, the literature emphasises that the MD method is usually employed to investigate temporal variation (Della Porta, 2008; Gerring, 2004; Gerring, 2007a; Mill, 1888) whereas MA is usually employed to account for spatial variation (Bartolini, 1993; Skocpol, 1984), especially in the analysis of rare or even unique events (Skocpol, 1991). In fact, in the analysis of a phenomenon the comparison between the situation before and after that phenomenon occurs represent one of the most common applications of the MD method (Hancké, 2009). Conversely, comparing two spatially distant social or political units allows to control for a variety of differences between them thus representing one of the most common application of the MA method. Using Gerring's (2004; 2007a) categorisation of case study research the MA method is more often used for cross-sectional research designs whereas its counterpart for longitudinal research designs. Table 1 provides a summary of the discussion in this section.

\section{(Table 1)}

\section{The Lakatosian Research Program}

In this work I posit that the two Millian methods perform different but complementary functions if nested into the Lakatosian research program. From an epistemological perspective viii, a Lakatosian approach to research maximises the utility of comparative research in that the researcher is able to achieve both theoretical and empirical progress where using the Millian methods in their two methodological variants: as a concept formation tool and as a inferential tool. In this vein, the two Millian methods perform different but complementary functions and optimally they should be used in conjunction (what Mill, 1888, calls the joint method of agreement and difference). This work explores the functions performed by the two methods both as concept formation tools (aiming at theoretical progress) and as inferential tools (aiming at empirical progress) after briefly introducing the concept of the Lakatosian research program.

In the last years increasing attention on the part of what Mahoney (2010) terms the new methodology literature has been devoted to the process of embedding social research in the broader discussion on the philosophy of science (George \& Bennett, 2005; Hall, 2013; Hancké, 2009; Schmitter, 2008; Vennesson, 2008). Nonetheless, the new methodology literature has hitherto limited the discussion on the philosophy of science to how to embed process tracing, namely the analysis of within case variation (George \& Bennett, 2005), into 
prior theoretical knowledge. Even when the philosophical debate is explicit as in Vennesson (2008), whose applied rationalism provides a nuanced discussion on the different stages of knowledge, it is circumscribed to the different conceptualizations of case study research with no attention paid to the theoretical and empirical progress of science. Likewise, although the conceptualization of research as a cyclical endeavour has already been embraced by historical sociology (Skocpol, 1984; Skocpol \& Somers, 1980) no mention is present on how science can progress along that cycle. Furthermore, the tendency to consider that approach as idiosyncratic to that particular discipline is still dominant in the methodology literature (Hall, 2013; Rohlfing, 2013). In this vein the concept of research program borrowed from the philosopher Imre Lakatos (Lakatos, 1970; Lakatos \& Musgrave, 1970) can provide epistemological bases for comparative case study research. Other scholars have emphasized the advantages of the Lakatosian philosophy of science as applied to social research to assay its progress (Hall, 2003; Hall, 2013; Hancké, 2009). Nevertheless, no discussion is present in the literature on social research as an overarching endeavor comprising a series of functions performed by different methods which ultimately leads to theoretical and empirical progress. In other words, no discussion is present on how to link methods to their methodologies and in turn to epistemological premises.

In the philosophy of science two criteria which demarcate science from pseudoscience had been identified until the 1970s: verification and falsification (Bartley, 1968; Bunge, 1982; Lakatos, 1970). Verificationism and falsificationism are rather straight forward: a statement is scientific in that respectively verifiable or falsifiable. The former approach was developed in the 1930s by the Vienna Circle whereas the latter is associated with Popper's work (1962). Although not yet completely passé in social research (Waltz, 2003) the falsificationist approach was harshly criticized for not considering the impossibility of disentangling facts from theory. The conclusions to which most philosophers of science came in the 1970s was that theories cannot be proved or disproved with facts. An alternative theory of scientific change was provided by (Kuhn (1974); 1996) who distinguished normal science from its rare revolutionary moments on which philosophers of science had theretofore focused. According to Kuhn (1974) normal science develops through puzzle solving, namely small adjustments of the theory in order to account for new empirical evidence. Although the puzzle solving criterion overcame the issue of assaying theories in mere empirical terms two issues were associated with Kuhn's $(1974 ; 1996)$ theories: the incompatibility of paradigms and the nonrational criterion to appraise paradigms (Elman \& Elman, 2003b). In fact, two or more Kuhnian paradigms cannot coexist and the dominant paradigm is such only thanks to the assent of the research community (Elman \& Elman, 2003b): no guidelines to appraise a paradigm are supplied. 
In counterposition to the non-rationality of Kuhnian philosophy and to the focus on individual theories of Popperian philosophy Lakatos (1970) introduced a sophisticated variant of falsificationism in which the unit to be appraised in scientific terms is not an individual theory but a series of successive and interrelated theories, namely the research program. Lakatos' (1970) philosophy of science explains how science develops and, differently from Kuhn's $(1974 ; 1996)$, suggests how this trajectory is to be appraised (Elman \& Elman, 2003b). The research program is composed by four elements: the hard core, the negative heuristic, the protective belt and the positive heuristic (Elman \& Elman, 2003a, 2003b). The hard core represents the fundamental premises on which the theory part of the research program relies, such as the focus on rational and utility maximizing actors in political economy (Austen-Smith, 2009): those premises are specified in the negative heuristic. The hard core cannot be empirically tested nor disproved otherwise the creation of a new research program is necessary. The protective belt consists of a series of propositions which can be empirically tested and periodically adjusted (Elman \& Elman, 2003b), such as the assumption certain strands of political economy take that different national political economic institutions necessarily incentivize divergent patterns of action among societal actors. The positive heuristic contains the guidelines for the production of new theories within the research program: usually they refer to the explananda, such as the explanation on how economically motivated actors interact in the political arena in political economy (Wittman \& Weingast, 2009).

The Lakatosian research program has been associated with a view of research as a threecornered (Hancké, 2009) or even four-cornered fight (Schmitter, 2008) between the old theory $T_{1}$, the aberrant fact, the new theory $T_{2}$ and the null hypothesis derived from the latter. In this vein, the Lakatosian research program is associated with a cyclical view of research, already familiar to several strands of social sciences, for instance historical sociology. Nonetheless, the major difference between the Lakatosian conception of research program and that cyclical view of research is the progress research achieves. The Lakatosian research program may be summarised as follows. While addressing the theory $T_{1}$ the researcher finds deviant empirical evidence which cannot be explained. Accordingly, the researcher proceeds by altering the assumptions of the protective belt of $T_{1}$ the researcher derives a theory $T_{2}$ which explains more phenomena than the previous theory $T_{1}$ (what it is termed theoretical progress) (Lakatos, 1970; Lakatos, Feyerabend, \& Motterlini, 1999; Lakatos \& Musgrave, 1970). Then, the researcher finds empirical support for $\mathrm{T}_{2}$ (what it is termed empirical progress). This is graphically summarised in Figure 3. 


\section{The Political Economy of Redistribution as a Research Program}

In this this section I take the political economy of redistribution as an example of a research program. I define political economy as a discipline which analyses the interrelation between politics and economy (Wittman \& Weingast, 2009) through formal modelling in positive political theory (Austen-Smith, 2009). In Lakatosian terms, the hard core of the political economy of redistribution as a research program is represented by the assumption of rational and utility maximiser actors and the positive heuristic by the explanation of the creation and development of the welfare state through (sometimes implicit) formal modelling. In this section I demonstrate that the political economy of redistribution has scientifically progressed by means of the introduction of increasingly explanatorily powerful theories, namely theories based on more encompassing theoretic models able to explain novel facts and which in turn have found empirical support. Indeed, the refinement the literature has periodically applied to the assumptions of the theoretic models to explain the political economy of redistribution makes the political economy of redistribution the perfect example to show how science should progress according to the research program.

The political economy of redistribution may be divided into three main strands. The first strand emerged in the 1950s/1960s (Arrow, 1963; Downs, 1957; Olson, 1965, 1982) and it employed collective preference theory conceiving the welfare state as epiphenomal to individual behaviours (Goldthorpe, 1984; Hall \& Taylor, 1996). The main assumption of the protective belt was that the fixed preferences of rational utility maximiser actors smoothly aggregate and they are automatically transposed into authoritative decisions on redistribution. In the study of redistribution exemplar of this strand is the median voter theorem rejuvenated by Meltzer and Richard (1981) who predicted that as a reaction to universal suffrage contemporary welfare regimes would have been characterised by convergence towards increasing redistribution. The rationale was that the lower the income of the median voter, is and the higher the demand for redistribution would be. Indeed, as the income of the share of population necessary to win the elections, namely 50 per cent (of which the median voter is representative), decreases the demand for more redistribution increases.

The second stream introduced (non-cooperative) game theory into political economy giving analytic relevance to political, economic and cultural institutions (Austen-Smith, 2009). As a reaction to the empirical evidence which put into question the existence of a common functional logic across countries (Goldthorpe, 1984), namely the aberrant fact for the 
collective preference theory, this stream focused on industrial and class conflict by using non-cooperative game theory. The most prominent example in the study of redistribution is the power resource theory (Esping-Andersen, 1990; Esping-Andersen \& Korpi, 1984; Korpi, 1983; O'Connor \& Olsen, 1998). The latter claimed that although social classes have fixed preferences vis-à-vis redistribution institutions, such as the electoral system but also cultural values, mediate how those preferences aggregate and transpose into authoritative decisions on redistribution. For instance, although across the world working classes share the same preferences towards redistribution and although those preferences tend to diverge from business' preferences, labour acted differently in Mediterranean countries and in the UK in the 1980s. Indeed, in the former the state provided a wide array of social services, such as family benefits, perhaps due to the primary role family has historically enjoyed in Catholic societies. In this way the working class reduced their demand for more traditional redistribution, namely taxation. Contrariwise, in the more individualistic British society no social benefits were provided thus fuelling the demand for more traditional redistribution and triggering a decade of social unrest. In conclusion, the interaction between conflicting societal actors with divergent preferences assumes different forms across countries due to the differences in economic, political and cultural institutions.

The third and contemporary strand of the political economy of redistribution relies on mixedmotive game theory. In counterposition to the strands introduced above Cusack et al. (2007) and Iversen and Soskice (2009) argue that business and labour do not necessarily have conflicting interests. For instance, where the benefits of economic coordination outweigh the costs of redistribution business and labour tend to coordinate in the political realm. In other words, where employers and employees already coordinate in the economic realm, for instance due to the management of vocational training and professional education (Culpepper, 2001), their preferences coincide also in the political realm. This implies that actors have different preferences across multiple issues involved in the same game, such as redistribution and economic coordination.

It should be noticed how the evolution of the political economy of redistribution can be assayed as a research program. Indeed, each strand introduced above modifies the assumptions of the protective belt of the previous one. The median theorem voter as applied to redistribution (Meltzer \& Richard, 1981) claims that since the median voter has an income below average, the electoral aggregation of preferences will automatically lead to more 
redistribution ${ }^{1}$. As a logical consequence, the more uneven the allocation of wealth, the higher the redistribution will be (Iversen, 2008). Nonetheless, several subsequent works underlined that countries such as the US, where wealth is unevenly allocated, tend to redistribute less than countries with more egalitarian economies, such as the Nordic countries (Esping-Andersen, 1990; Moene \& Wallerstein, 2001). This aberrant fact required an adjustment of the protective belt and the formulation of a new theory. In doing so, EspingAndersen (1990) and his power resource theory emphasised the differences across welfare regimes: different institutions mediate the effect class struggle has on redistribution. In this vein, the lack of the role of political and cultural institutions in the collective preference theory represents the protective belt which needed to be identified and modified in order for the research to progress theoretically.

The non-cooperative game theory, on which the power resource theory is based, could not explain why some countries, such as Germany, were characterised by high redistribution. Indeed, as it was common belief in the literature (Lipset \& Rokkan, 1967; Rokkan, 1970) proportional systems were deemed to be established by the dominant elites of the $19^{\text {th }}$ century so as to fragment power and avoid the situation where the increasing voting population would demand more and more redistribution. Yet, Cusack, Iversen, and Soskice (2007) demonstrated that the need for economic coordination led to the tendency to redistribute more on the part of the dominant elites. Indeed, in Germany the necessity of coordination between employers and employees was crucial for the industrial revolution of the $19^{\text {th }}$ century and it has become a common practice since then: this has led to a generous welfare state (Iversen \& Soskice, 2006). In this case the modification of the protective belt rests in the shift from non-cooperative game theory, where actors have fixed preferences across issues which usually are conflictual across the society, to mixed-motive game theory, where actors can assume different preferences across issues thus leading also to cooperation between business and labour, for instance. Again, the theoretical progress is achieved thanks to the fact that the mixed-motive games assume less restrictive assumptions thus explaining more facts than non-cooperative ones.

Before proceeding to the ensuing section the concept of the hard core and negative heuristic deserve further discussion. In a recent study Aarøe and Petersen (2013) analyse the creation and development of the welfare state from a new perspective: evolutionary psychology. Those authors posit that attitudes towards redistribution and thus the modern welfare state are psychologically related to the state of hunger. Indeed, throughout history,

\footnotetext{
${ }^{1}$ The income of the median voter is usually below the average income since the distribution of income in any society is skewed towards the right.
} 
resource sharing has become common in situations of temporary hunger, such as famines. They support this statement through an experiment by using blood glucose level in individuals as an indicator of hunger and by using games to measure individuals' propensity to resource sharing. This theory explains something which the theories introduced above cannot explain, such as short term attitudes towards redistribution and thus medium term adjustments in welfare state within the same country, and it finds strong empirical confirmation through a natural experiment. Furthermore, this study (partially) follows the positive heuristic of the research program of the political economy of redistribution, namely it aims to explain the welfare state. Nonetheless, it creates a new research program: what may be called the (evolutionary) psychology of the welfare state. In fact, differently from the other theories described in this section it modifies the hard core thus breaking the assumption at the basis of the negative heuristic of the political economy of redistribution: rational and utility maximiser actors. The theory proposed by Aarøe and Petersen (2013) posit the individuals are motivated by an historically built psychological attitude towards hunger.

\section{Nesting Comparative Case Study Research into the Lakatosian Research Program}

After having introduced Lakatos' philosophy of science and its main concept, namely the research program, as a way in which science evolves and also as a series of guidelines to assay a body of theories two points deserve further attention. Lakatos' (1970) philosophy of science has already been mentioned in social research both in methodological (Hall, 2003; Hall, 2013; Hancké, 2009) as well as substantive worksix. Nonetheless, very few works really unpack the concept of research program thus limiting the discussion to a cyclical view of research where theory and empirics interact between one another. For instance, the literature has hitherto paid little attention to the concepts of theoretical and empirical progress. In fact, a new theory in order to be progressive should predict novel facts and find empirical confirmation. Although confusion prevails over the term "novel fact" this work employs the definition put forward by Lakatos, Worrall, and Currie (1980) and used in Elman and Elman (2003b). A fact is defined as novel in that it does not play a role in the development of the theory. In other words, explaining the aberrant fact for $T_{1}$ does not suffice for $T_{2}$ to lead to theoretical progress. Furthermore, the novel facts predicted by $T_{2}$ must find empirical confirmation. Nonetheless, there is agreement among scholars that the empirical test of the new theory can be partial or at least provided at a later stage.

Secondly, this work aims to link together epistemology, methodology and methods. The argument put forward in this section is that comparative case study research in its concept formation methodology is functional to the theoretical progress in the research program, namely to the identification and prediction of novel facts, whereas in its inferential 
methodology to the empirical progress, namely the confirmation of the new theory. The discussion commences with concept formation being logically prior to causal inference ${ }^{x}$.

The Millian methods perform different but complementary functions when used as concept formation tools. They can, indeed, be placed on different levels on what Sartori (1970) terms the ladder of abstraction thus allowing the researcher to climb it. The MD method arguably develops concepts per genus et differentiam resulting in what George and Bennett (2005) define as middle range typological theories. As illustrated in Figure 3, starting from the genus $T_{1}$, which contains the concepts $I V_{2}$ and $I V_{3}$ and $D V$, the researcher re-categorises such a genus according to the new categorisation $X_{1}$ identifying thus the new concept $I V_{1}$. In other words, through the MD method the researcher differentiates the genus $T_{1}$ into a new categorisation by altering the assumptions of the protective belt of $T_{1}$. The result is a middle range categorical theory in the form 'if $X_{1}$ then $I V_{1}$ causes $D V$, if non- $X_{1}$ then $I V_{2}\left(\right.$ and/or $\left.I V_{3}\right)$ causes DV'. It should be noticed that at this stage the concepts $I V_{1}, I V_{2}$ and $I V_{3}$ and DV have similar characteristics in terms of extension and intension. Then, by applying the MA method the author reconciles the new categorisation into a new genus $T_{2}$ (containing the concepts $X_{1}$ and $Y$ ). By comparing similar instances the researcher excludes everything different from the concept $X_{1}$ and $Y$ : he or she creates the new genus $T_{2}$ (and the related concepts $X_{1}$ and $Y$ ) ex adverso, namely by negation (Sartori, 1970).

Sartori (1970 p.1044) argues that medium level categories (what George and Bennett, 2005, defines middle range typological theories) are created through 'comparisons among relatively homogenous contexts'. As seen above, the homogeneity (i.e. comparability) of cases is dictated by the genus $T_{1}$. In doing so, the researcher compares cases belonging to the same genus in order to identify the aberrant facts which do not fit that genus and the related concepts ( $A$ and $B$ in the figures). Then, he/she goes further by identifying and altering the assumptions of the protective belt on which $T_{1}$ relies: the categorisation $X_{1}$ in Figure 3 . Then, the researcher moves forward by comparing similar cases according to the new concept $X_{1}$. In other words, he/she defines the new genus $T_{2}$ (and the related concepts) by negation. The result is the genus $T_{2}$ characterised by concepts, such as $X_{1}$ and $Y$, with less intension and more extension (Sartori, 1970) then those at the basis of the genus $T_{1}$, such as $\mathrm{IV}_{2}, \mathrm{IV}_{3}$ and DV. As a conclusion, the genus $\mathrm{T}_{2}$ brings theoretical progress to the research program.

The comparative methods as inferential tools make research progress empirically according to the guidelines set out by the Lakatosian philosophy of science. Indeed, it theoretically guides the researcher on the comparability of cases as well as it leaves the full burden of the empirical confirmation of the new theory $T_{2}$ to future endeavours ${ }^{\mathrm{xi}}$. Differently from what 
argued by the literature cases are not comparable per se, maybe because they represent countries in the same geographical area (Lijphart, 1971). As claimed by Bloch (1934) 'the unity of place is disorder [...] only the unity of problem makes a centre' (in Skocpol and Somers, 1980 p.194): what makes cases comparable is the fact that they can be compared by using concepts belonging to the same genus (Sartori, 1970), namely they are comparable according to the theory $T_{1}$ the researcher addresses. This attenuates the issue of overdetermination, namely the risk of falsely rejecting a true hypothesis, in that the researcher implicitly compares his/her own cases with the hypothetical population of cases identified by the theory $T_{1}$. As applied to Figure 2 , the researcher implicitly compares the cases $A$ and $B$ with the population of cases which includes also the case $C$ which in turn allows to control for $\mathrm{IV}_{0}$. Otherwise, if $\mathrm{IV}_{0}$ does not belong to the genus $T_{1}$ the researcher is not interested in controlling for it in that it falls outside the scope of the research program.

In this vein, Figure 2 shows the application of the MD method: in this case the researcher can affirm that the independent variable $\mathrm{IV}_{1}$ causes the dependent variable $\mathrm{DV}$ by eliminating the potential explanations offered by $T_{1}$ (i.e. $I V_{2}, I V_{3}$ and $I V_{4}$ ). The use of the $M A$ method would lead to the failure in rejecting the false hypotheses that $D V$ and $I V_{2} I V_{3}$ and IV are related, as shown in Figure 1. This demonstrates that equifinality and the related risk of failing to reject a false hypothesis can be overcome with the help of the MD method. Figure 1 shows the application of the MA method, which demonstrates that $X_{1}$ (and not $X_{2}$ or $X_{3}$ ) causes $Y$. It should be noticed that, as demonstrated above, the concepts (or variables in this case) $X_{1}$ and $Y$ contain the concepts (or variables) IV $I_{1}, I_{2} I V_{3}$ and DV. Accordingly, not only is the progress made by the research theoretically but also empirically. Indeed, theory $T_{2}$, which claims a causal relationship between $X_{1}$ and $Y$, is more explanatorily powerful than theory $T_{1}$ in that it explains the relationship between $I V_{2}, I V_{3}$ and $D V$ but also the one between $I V_{1}$ and $D V$, for instance. As seen above, the concepts $X_{1}$ and $Y$ are more extensive than $I_{1}, I V_{2}, I V_{3}$ and DV. Furthermore, the new theory $T_{2}$ finds (partial) empirical support.

Before proceeding to an example of how to apply the Lakatosian research program to comparative case study research, a consideration on causal inference is needed. Apart from few notable ground breaking works at the very beginning of 2000s (Goldthorpe, 2001), one of the main contributions of the new methodology has been a revamped attention to causal inference in the 2010s. The new methodology literature (Collier, 2011; Collier, Brady, \& Seawright, 2010a; Collier, Brady, \& Seawright, 2010b; Gerring, 2008; Hall, 2013; Mahoney, 2010) identifies two main modes of causal inference in qualitative research: covarational and mechanismic. Those two modes of causal inference entail different pieces of evidence and they are related to different methods. A mechanismic mode of causal inference relies on 
causal process observations as the main type of evidence (Collier, 2011; Collier et al., 2010a; Collier et al., 2010b) and it is underpinned by within case analysis, namely process tracing (George \& Bennett, 2005). Conversely, a covarational mode of causal inference relies on more traditional data set observations (Collier et al., 2010b) and it is used by comparative case study research, as used in this work. As done in Figure 1 and Figure 2, cases are divided into variables or factors (what Rihoux \& Ragin, 2009, term a configurational approach) and those which co-vary or those which do not are considered to be associated.

\section{The Political Economy of Corporate Governance as a Research Program and Comparative Case Study Research}

This section provides another example of a research program in social research, namely the political economy of corporate governance, and it shows how theoretical and empirical progress can be achieved by using the Millian methods in the two methodologies introduced above, namely concept formation and causal inference. The choice of this research program as an example is dictated by the illustrative purposes of this section. Indeed, a single work, namely Culpepper's (2011) Quiet Politics and Business Power: Corporate Control in Europe and Japan, employs both the MD method and the MA method in order to bring theoretical and empirical progress in that research programme. Accordingly, that work perfectly exemplifies the link between epistemology, methodology and methods on which this work focuses.

Culpepper's (2011) work investigates the corporate governance reform in Germany, France, Netherlands and Japan ${ }^{\mathrm{xii}}$ by starting from a specific aspect: the market for corporate control. The latter refers to the role of the equity market in corporate takeovers, namely whether the acquisition of a company follows exclusively economic rules or it is regulated by law, for instance. The major theories at the time of writing were the partisan theory (Cioffi \& Höpner, 2006) and the coalitional theory $\left(T_{1}\right)$ (Gourevitch \& Shinn, 2005), which emphasised the role of partisanship $\left(\mathrm{IV}_{2}\right)$ and the role of cross-class coalitions $\left(\mathrm{IV}_{3}\right)$ in the creation of a passive market for corporate control (DV). In other words, those markets where (at least certain) companies could not be acquired through the equity market, namely by simply buying shares, such as in Germany and Netherlands, were explained by focusing on the economic policy promoted by social democratic parties in power and on the role of trade unions in defending firms against liberalisation. Nonetheless, those two theories could not explain the increase in hostile takeovers in some countries, such as in France, and not in others, such as in Germany, as a consequence of the financial globalisation in the 1990s (the aberrant fact, namely cases A and B in figures). The in-depth analysis of those cases conducted by 
the researcher led to the discovery of the aberrant fact for the theory $T_{1}$ and to the identification of an alternative explanation: the difference in managers' preferences between countries $\left(\mathrm{IV}_{1}\right)$. This explanation was formulated thanks to the use of the MD method by comparing the French and German reforms of the market for corporate control ${ }^{\mathrm{xiii}}$ (or lack of in the latter) in the 1990s (i.e. the cases $A$ and $B$ ) where the preferences of managers $\left(\mathrm{IV}_{1}\right)$ differed but where partisanship $\left(\mathrm{IV}_{2}\right)$ and cross-class coalitions $\left(\mathrm{IV}_{3}\right)$ did not play a role and where different outcomes (DV) (consistent with managers' preferences) occurred.

The researcher went further by altering the assumptions of the protective belt on which T1 relied, namely that political institutions always matter, and identifies the factor $\mathrm{X}_{1}$ : issue salience. The result was a middle range theory: where issue salience is low $\left(X_{1}\right)$ managers' preferences $\left(\mathrm{IV}_{1}\right)$ determine the reform of the market for corporate control (DV). The concepts that were part of that middle range theory were elaborated per genus et differentiam, namely by differentiating the categorization of concepts according to a new genus, namely the theory $T_{2}$. This re-categorization of $T_{1}$ led the author to the theory $T 2$ characterised by more extensive concepts: issue salience $\left(X_{1}\right)$ and the political economy of corporate governance reform $(Y)^{\mathrm{xiv}}$. In order to investigate that hypothesis and to generate a new universal theory the use of the MA method was necessary. Thus the level of analysis was shifted away from the market for corporate control in Germany and France and to the reform of political economy of corporate governance. By eliminating all the differences between France and Germany, mainly the political economic institutions such as the electoral system (majoritarian v. proportional), the mode of interest representation (pluralist v. neo-corporatism) and the variety of capitalism (liberal market economy v. coordinated market economy), the researcher concludes that issue salience is related to business power in corporate governance reform. It should be noticed that the latter is a more extensive and less intensive concept than the reform of market for corporate control. The finding was that regardless the individual country (or the issue at stake) managers co-opt the decisionmaking process when the salience of an issue is low: this is an ex adverso definition. The author identified a universal theory $\mathrm{T}_{2}$ : 'the theory of quiet politics implies that the political power of organized business is insensitive to the differences among the political institutions of advanced democracies' (Culpepper, 2011 p.179). Table 2 summarizes that two stage process. In conclusion, $T_{2}$ represents a progress in the research program being explanatorily more powerful than $T_{1}$ in that relying on more extensive concepts and being also (partially) empirically supported by evidence. 
First of all, it should be noticed that the theory of quiet politics does not modify the hard core thus respecting the negative heuristic: the theory assumes rational and utility maximiser actors, as it is the case for political economy. It is argued that business rationally adapts its lobbying strategies according to the institutional arena and whether the issues gains public and political attention. In this vein, it is similar to the coalitional and partisan theories. Furthermore, it follows the positive heuristic of the political economy of corporate governance, namely the explanation of corporate governance reforms in advanced democracies. Nonetheless, the theory of quiet politics modifies the assumptions in the protective belt on which $T_{1}$ relied, namely the fact that different institutions always incentivise different patterns of behaviour. Furthermore, $T_{2}$ represents a genuine theoretical progress in that not only does it explain the aberrant facts which the old theories could not account for but it also explains something more. That theory predicts that issue salience $\left(\mathrm{X}_{1}\right)$ determines the political power of organised business in corporate governance reform ( $Y$ ). If issue salience $\left(X_{1}\right)$ is high the role of partisanship $\left(\mathrm{IV}_{2}\right)$ or of broader societal actors $\left(\mathrm{IV}_{3}\right)$ determine the reform of the market for corporate control (DV), as claimed by $T_{1}$. Yet, the theory $T_{2}$ explains also the scenario when issue salience is low, namely that organised business $\left(\mathrm{IV}_{1}\right)$ determines the reform of the market for corporate control (DV). In other words, it also explains the increase in hostile takeovers in countries, such as France, which the previous theories could not account for. On top of that, that theory explains also other aspects of corporate governance which are not used in its construction and which is not explained by the previous theories: for instance, the reform in executive pay in several countries in the 1990s, as demonstrated by Culpepper (2011) in the last section of the book.

\section{Conclusion}

In this work I argue that in order to fully exploit the comparative case study methods in social sciences the researcher has to take clear stances at the epistemological level and, relatedly, at the methodological level. The link between epistemology, methodology and methods needs to be substantiated. The Millian comparative methods allow research to progress both theoretically and empirically according to the research program. The latter represents the core tenet of Lakatos' philosophy of science and it sets out a series of epistemological guidelines according to which science (should) evolves. In their two methodological variants the Millian comparative methods provide the concept formation tools necessary to formulate a more theoretically powerful new theory as well as the inferential tools to (partially) confirm that theory. 
Three conclusions may be drawn. Firstly, the discussion of the application of the Millian methods in social research demonstrates how the method of agreement (MA) is not inferior to the method of difference (MD) as sustained by the literature. Rather, they perform complementary functions indispensable to the researcher. Secondly and accordingly, the researcher can provide any body of literature with a substantial contribution by using comparative case study research. Last but not least, this work is in line with the new methodology literature which have recently argued in favour of the academic dignity of case study research. Rather, I conclude this work with a provocative claim: if used singularly and not in combination, comparative case study research is methodologically superior to its quantitative nemesis, namely statistical research. The former, indeed, is methodologically functional to theoretical progress as well as empirical progress whereas the latter whilst performing better in empirical progress is not functional to theoretical progress at all. The reason being that although statistical research can better cope with issues such as overdetermination and equifinality thus providing a theory with a more sound empirical investigation it does not perform a function which is crucial for the progress of research, namely concept formation. 
Figures and Tables

Figure 1. The MA Method.
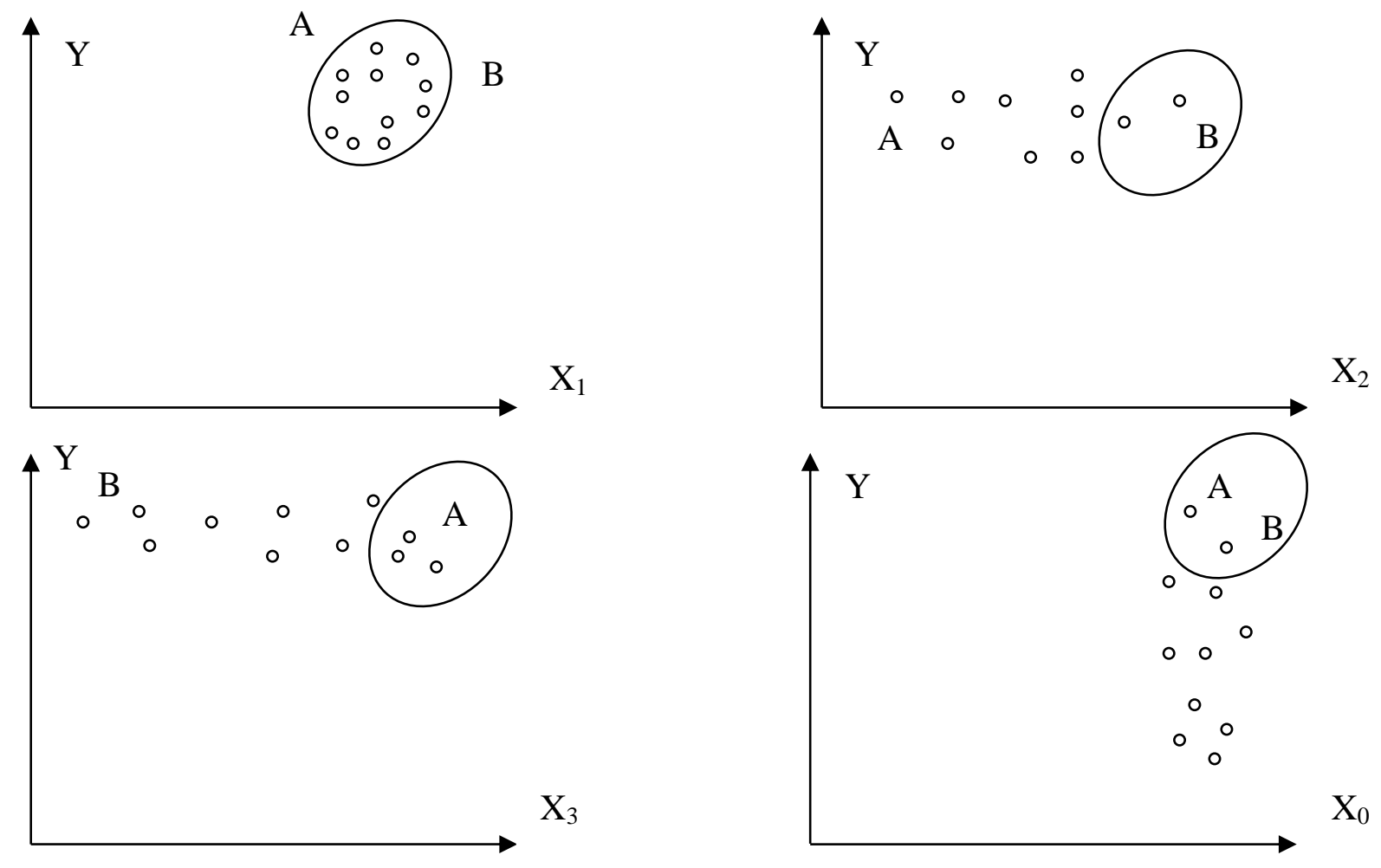

\begin{tabular}{|l|l|l|}
\hline MA & A & B \\
\hline$Y$ & 1 & 1 \\
\hline$X 1$ & 1 & 1 \\
\hline$X 0$ & 1 & 1 \\
\hline X2 & 0 & 1 \\
\hline$X 3$ & 1 & 0 \\
\hline
\end{tabular}


Figure 2. The MD Method.
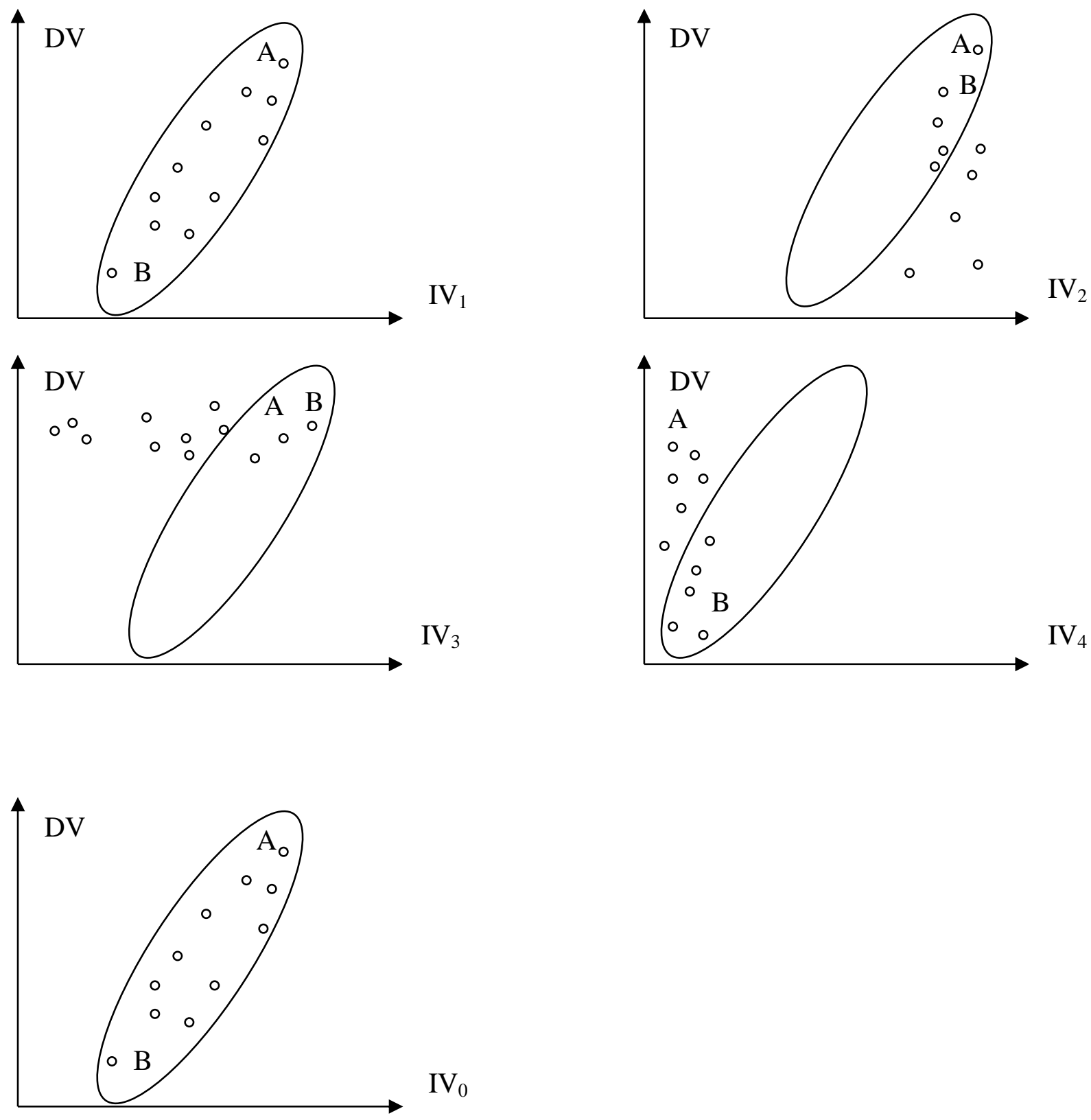

\begin{tabular}{|l|l|l|}
\hline MD & A & B \\
\hline$D V$ & 1 & 0 \\
\hline$I V 1$ & 1 & 0 \\
\hline$I V 0$ & 1 & 0 \\
\hline IV2 & 1 & 1 \\
\hline IV3 & 1 & 1 \\
\hline IV4 & 0 & 0 \\
\hline
\end{tabular}


Table 1. The MD and the MA Methods: a Comparison.

\begin{tabular}{|l|l|l|}
\hline & MD & MA \\
\hline Scope of claim & Internal validity & External validity \\
\hline Content of claim & Necessary cause & Sufficient cause \\
\cline { 2 - 3 } & Cause of an outcome & Outcome of a cause \\
\hline Practical considerations & & $\begin{array}{l}\text { Low variance in the outcome } \\
\text { (e.g. rare events) }\end{array}$ \\
\hline Type of variance & Temporal & Spatial \\
\hline Main issue & Overdetermination & Equifinality \\
\hline
\end{tabular}


Figure 3. The Research Program.

Universal theory

T1: IV2 (or IV3,

IV4) causes DV

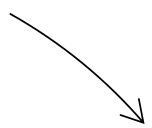

$\mathrm{A}$ and $\mathrm{B}$ do not fit T1

T2: X1 causes Y

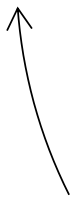

Middle range theory: if $\mathrm{X} 1$ then IV1 causes DV
Identification and alteration of the protective belt 
Table 2. The MD v. MA Methods: an Example.

\begin{tabular}{|c|c|c|}
\hline MD & $\begin{array}{l}\text { French reform of the market } \\
\text { for corporate control in } \\
1990 \mathrm{~s}\end{array}$ & $\begin{array}{l}\text { German reform of the market } \\
\text { for corporate control in } 1990 \mathrm{~s}\end{array}$ \\
\hline $\begin{array}{l}\text { Corporate governance } \\
\text { reform }\end{array}$ & $1-$ reform & 0 - no reform \\
\hline Managers' preferences & $\begin{array}{l}1 \text {-managers' preferences in } \\
\text { favour of reform }\end{array}$ & $\begin{array}{l}\text { O- managers' preferences } \\
\text { against reform }\end{array}$ \\
\hline Societal actors & $\begin{array}{l}0 \text { - no role of cross-class } \\
\text { coalitions }\end{array}$ & $\begin{array}{l}0 \text { - no role of cross-class } \\
\text { coalitions }\end{array}$ \\
\hline Partisanship & 0- no role of parties & 0 - no role of parties \\
\hline MA & Corporate governance reform & Corporate governance reform \\
\hline $\begin{array}{l}\text { Business power in policy } \\
\text { change }\end{array}$ & 1-business power & 1-business power \\
\hline Salience & 1-low salience & 1 -low salience \\
\hline $\mathrm{VoC}$ & 0-LME & 1-CME \\
\hline Electoral system & 1-majoritarian & 0-proportional \\
\hline $\begin{array}{l}\text { Mode of interest } \\
\text { representation }\end{array}$ & 1-pluralism & 0-neocorporatism \\
\hline
\end{tabular}




\section{References}

Aarøe, L., \& Petersen, M. B. (2013). Hunger Games: Fluctuations in Blood Glucose Levels Influence Support for Social Welfare. Psychological Science, 20(10), 1-7.

Arrow, K. J. (1963). Social Choice and Individual Values: Yale University Press.

Austen-Smith, D. (2009). Economic Methods in Positive Political Theory. In D. A. Wittman \& B. R. Weingast (Eds.), The Oxford Handbook of Political Economy. Oxford: Oxford University Press.

Bartley, W. W. (1968). Theories of demarcation between science and metaphysics. In I. Lakatos \& A. Musgrave (Eds.), Problems in the Philosophy of Science, Proceedings of the International Colloquium in the Philosophy of Science (Vol. 3, pp. 40-64). Amsterdam: NorthHolland Publishing Company.

Bartolini, S. (1993). On Time and Comparative Research. Journal of Theoretical Politics, 5(2), 131-167.

Bloch, M. (1934). Une Etude Regionale: Geographie ou Historie? Annales d'Historie Economique et Sociale.

Bunge, M. (1982). Demarcating Science from Pseudoscience. Fundamenta Scientiae, 3, 369-388.

Cioffi, J. W., \& Höpner, M. (2006). The Political Paradox of Finance Capitalism: Interests, Preferences, and Center-Left Party Politics in Corporate Governance Reform. Politics \& Society, 34(4), 463-502.

Collier, D. (2011). Understanding Process Tracing. PS: Political Science \& Politics, 44(04), 823-830.

Collier, D., Brady, H. E., \& Seawright, J. (2010a). Outdated Views of Qualitative Methods: Time to Move On. Political Analysis, 18(4), 506-513.

Collier, D., Brady, H. E., \& Seawright, J. (2010b). Sources of Leverage in Causal Inference: Toward an Alternative View of Methodology. In H. E. Brady \& D. Collier (Eds.), Rethinking Social Inquiry Diverse Tools, Shared Standards: ROWMAN \& LITTLEFIELD PUBLISHERS, INC.

Culpepper, P. D. (2001). Employers, Public Policy, and the Politics of Decentralized Cooperation in Germany and France. In P. A. Hall \& D. Soskice (Eds.), Varieties of Capitalism: The Institutional Foundations of Comparative Advantage. Oxford: Oxford University Press.

Culpepper, P. D. (2011). Quiet Politics and Business Power: Corporate Control in Europe and Japan. Cambridge: Cambridge University Press.

Cusack, T. R., Iversen, T., \& Soskice, D. (2007). Economic Interests and the Origins of Electoral Systems. American Political Science Review, 101(03), 373-391.

Della Porta, D. (2008). Comparative analysis: case-oriented versus variable-oriented research. In D. Della Porta \& K. Micheal (Eds.), Approaches and Methodologies in the Social Sciences: A Pluralist Perspective. Cambridge, UK: Cambridge University Press.

Downs, A. (1957). An Economic Theory of Political Action in a Democracy. Journal of Political Economy, 65(2), 135-150.

Elman, C., \& Elman, M. F. (2003a). Introduction. Appraising Progress in International Relations Theory. In C. Elman \& M. F. Elman (Eds.), Progress in International Relations Theory: Appraising the Field: MIT Press. 
Elman, C., \& Elman, M. F. (2003b). Lessons from Lakatos. In C. Elman \& M. F. Elman (Eds.), Progress in International Relations Theory: Appraising the Field: MIT Press.

Esping-Andersen. (1990). The three worlds of welfare capitalism. Cambridge: Polity.

Esping-Andersen, G., \& Korpi, W. (1984). Social Policy and Class Politics in Postwar Capitalism: Scandinavia, Austria and Germany. In J. Goldthorpe (Ed.), Order and Conflict in Contemporary Capitalism. Oxford: Clarendon.

Geddes, B. (1990). How the Cases You Choose Affect the Answers You Get: Selection Bias in Comparative Politics. Political Analysis, 2(1), 131-150.

George, A. L., \& Bennett, A. (2005). Case Studies and Theory Development in the Social Sciences: MIT Press.

Gerring, J. (2004). What Is a Case Study and What Is It Good for? The American Political Science Review, 98(2), 341-354.

Gerring, J. (2007a). Case Study Research: Principles and Practices: Cambridge University Press.

Gerring, J. (2007b). Is There a (Viable) Crucial-Case Method? Comparative Political Studies, 40(3), 231-253.

Gerring, J. (2008). The Mechanismic Worldview: Thinking inside the Box. British Journal of Political Science, 38(1), 161-179.

Goertz, G. (2006). Social science concepts: A user's guide: Princeton University Press.

Goertz, G., \& Levy, J. S. (2007). Causal Explanation, Necessary Conditions, and Case Studies. In G. Goertz \& J. S. Levy (Eds.), Explaining War and Peace: Case Studies and Necessary Condition Counterfactuals (pp. 9-45). New York: Routledge.

Goldthorpe, J. H. (1984). The end of convergence: Corporatist and dualist tendencies in modern Western societies. In J. H. Goldthorpe (Ed.), Order and conflict in contemporary capitalism. Oxford: Clarendon

Goldthorpe, J. H. (2001). Causation, Statistics, and Sociology. European Sociological Review, 17(1), 1-20.

Gourevitch, P. A., \& Shinn, J. (2005). Political Power and Corporate Control: The New Global Politics of Corporate Governance: Princeton University Press.

Hall, P. A. (2003). Aligning Ontology and Methodology in Comparative Research. In J. Mahoney \& D. Rueschemeyer (Eds.), Comparative Historical Analysis in the Social Sciences (pp. 373-406). New York: Cambridge University Press.

Hall, P. A. (2013). Tracing the Progress of Process Tracing. Eur Polit Sci, 12(1), 20-30.

Hall, P. A., \& Taylor, R. C. R. (1996). Political Science and the Three New Institutionalisms*. Political Studies, 44(5), 936-957.

Hancké, B. (2009). Intelligent Research Design: A Guide for Beginning Researchers in the Social Sciences: OUP Oxford.

Iversen, T. (2008). Capitalism and Democracy. In D. A. R. a. B. R. Weingast (Ed.), The Oxford Handbook of Political Economy. Oxford, United Kingdom: Oxford University Press.

Iversen, T., \& Soskice, D. (2006). Electoral Institutions and the Politics of Coalitions: Why Some Democracies Redistribute More Than Others. American Political Science Review, 100(02), 165-181.

King, G., Keohane, R. O., \& Verba, S. (1994). Designing Social Inquiry: Scientific Inference in Qualitative Research: Princeton University Press.

Korpi, W. (1983). The Democratic Class Struggle. London: Routledge \& Kegan Paul. 
Kuhn, T. S. (1974). Logic of Discovery or Psychology of Research? In P. A. Schilpp (Ed.), The Philosophy of Karl Popper (Vol. xiv, pp. 798-819). Open Court: La Salle.

Kuhn, T. S. (1996). The Structure of Scientific Revolutions: University of Chicago Press.

Lakatos, I. (1970). Falsification and the Methodology of Research program. In I. Lakatos \& A. Musgrave (Eds.), Criticism and the Growth of Knowledge (pp. 91-197). Cambridge: Cambridge University Press.

Lakatos, I., Feyerabend, P., \& Motterlini, M. (1999). For and Against Method: Including Lakatos's Lectures on Scientific Method and the Lakatos-Feyerabend Correspondence: University of Chicago Press.

Lakatos, I., \& Musgrave, A. (1970). Criticism and the Growth of Knowledge: Volume 4: Proceedings of the International Colloquium in the Philosophy of Science, London, 1965: Cambridge University Press.

Lakatos, I., Worrall, J., \& Currie, G. (1980). The Methodology of Scientific Research Programmes: Volume 1: Philosophical Papers: Cambridge University Press.

Lange, P. (1984). Unions, Workers and Wage Regulation in Advanced Industrial Democracies: The Rational Bases of Consent. In J. Godthorpe (Ed.), Order and Conflict in Contemporary Capitalism: Clarendon.

Lijphart, A. (1971). Comparative Politics and the Comparative Method. The American Political Science Review, 65(3), 682-693.

Lipset, S. M., \& Rokkan, S. (1967). Party systems and voter alignments: cross-national perspectives: Free Press.

Mahoney, J. (2010). After KKV: The New Methodology of Qualitative Research. World Politics, 62(01), 120-147.

Meltzer, A. H., \& Richard, S. F. (1981). A Rational Theory of the Size of Government. Journal of Political Economy, 89(5), 914-927.

Mill, J. S. (1888). A System of Logic, Ratiocinative and Inductive: Being a Connected View of the Principles of Evidence and the Methods of Scientific Investigation: Harper \& Brothers.

Moene, K. O., \& Wallerstein, M. (2001). Inequality, Social Insurance, and Redistribution. The American Political Science Review, 95(4), 859-874.

O'Connor, J. S., \& Olsen, G. M. (1998). Power Resources Theory and the Welfare State: A Critical Approach : Essays Collected in Honour of Walter Korpi: University of Toronto Press.

Odell, J. S. (2001). Case Study Methods in International Political Economy. International Studies Perspectives, 2(2), 161-176.

Olson, M. (1965). The Logic of Collective Action: Public Goods and the Theory of Groups: Harvard University Press.

Olson, M. (1982). The Rise and Decline of Nations: Yale University Press.

Popper, K. (1962). Conjectures and refutations. The growth of scientific knowledge. New York: Basic Books.

Przeworski, A., \& Teune, H. (1970). The logic of comparative social inquiry: WileyInterscience.

Przeworski, A., \& Wallerstein, M. (1982). The Structure of Class Conflict in Democratic Capitalist Societies. The American Political Science Review, 76(2), 215-238.

Ragin, C. C. (1987). The Comparative Method: Moving Beyond Qualitative and Quantitative Strategies: University of California Press. 
Ragin, C. C. (2010). Turning the Tables: How Case-Oriented Research Challenges Variable-Oriented Research. In H. E. Brady \& D. Collier (Eds.), Rethinking Social Inquiry: Diverse Tools, Shared Standards: Rowman \& Littlefield Publishers, Inc.

Rihoux, B., \& Ragin, C. C. (2009). Configurational comparative methods : qualitative comparative analysis (QCA) and related techniques. Thousand Oaks: Sage.

Rohlfing, I. (2013). What is the Relation Between Comparative Historical Analysis and 'Ordinary' Case Studies? Eur Polit Sci, 12(1), 16-19.

Rokkan, S. (1970). Citizens, elections, parties: approaches to the comparative study of the processes of development: McKay.

Rose, R. (1991). Comparing Forms of Comparative Analysis. Political Studies, 39(3), 446462.

Sartori, G. (1970). Concept Misformation in Comparative Politics. The American Political Science Review, 64(4), 1033-1053.

Scharpf, F. W. (1984). Economic and Institutional Constraints of Full-Employment Strategies: Sweden, Austria, and Western Germany, 1973-1982. In J. Goldthorpe (Ed.), Order and Conflict in Contemporary Capitalism. Oxford: Clarendon

Schmitter, P. C. (2008). The design of social and political research. In D. Della Porta \& M. Keating (Eds.), Approaches and Methodologies in the Social Sciences: A Pluralist Perspective. Cambridge, UK: Cambridge University Press.

Skocpol, T. (1984). Vision and Method in Historical Sociology: Cambridge University Press.

Skocpol, T. (1991). States and Social Revolutions: A Comparative Analysis of France, Russia, and China: Cambridge University Press.

Skocpol, T., \& Somers, M. (1980). The Uses of Comparative History in Macrosocial Inquiry. Comparative Studies in Society and History, 22(2), 174-197.

Vennesson, P. (2008). Case studies and Process tracing. In D. Della Porta \& M. Keating (Eds.), Approaches and Methodologies in the Social Sciences (pp. 223-239). Cambridge: Cambridge University Press.

Waltz, K. N. (2003). Thoughts about Assaying Theories. In C. Elman \& M. F. Elman (Eds.), Progress in International Relations Theory: Appraising the Field: MIT Press.

Wittgenstein, L. (1958). Philosophical investigations. New Jersey: Prentice Hall.

Wittman, D. A., \& Weingast, B. R. (2009). The Reach of Political Economy. In D. A. W. a. B. R. Weingast (Ed.), The Oxford Handbook of Political Economy. Oxford: Oxford University Press.

\footnotetext{
${ }^{\mathrm{i}}$ Although I acknowledge that the clear definition of concepts is indispensable in any type of research, the argument is that differently from large $\mathrm{N}$ studies based on statistical analysis, for instance, comparative case study research can perform the concept formation function along with the inferential one common to any other method. Indeed, only the in-depth description of how a political or social phenomenon occurs in a given setting combined with the comparison of that instance with another in place in another setting can include all the relevant characteristics of that phenomenon and exclude all others. Accordingly, I argue that researchers should exploit this comparative advantage of comparative case study research also because categorisation is the condicio sine qua non for inferring causal relationships in social research (Sartori, 1970)

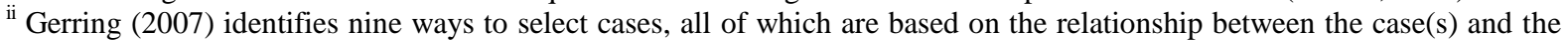
population of interest.

iii Other than their popularity in social science research, two other factors make the focus on those two methods relevant. Firstly, the combination of the method of agreement and the method of different represents an effective and efficient way to infer causal relations, as argued below. Secondly, they are the basis of the configurational/covarational approach to case study research, which is used also by more nuanced methods, such as Ragin's (1987) Qualitative Comparative Analysis (QCA).
} 


\footnotetext{
iv The discussion on those methods is contained in chapter 8 'Of The Four Methods Of Experimental Inquiry' of book III. I acknowledge that in that chapter Mill (1888) introduces two other methods: the method of concomitant variations and the method of residues. Nonetheless, the former lies on the quantification of factors, which is logically posterior to their identification and categorization (Sartori, 1970, George \& Bennett, 2005), and the latter represents a way to combine the results obtained through other inferential methods. Accordingly, being both logically and analytically posterior to the method of agreement and the method of difference they arguably do not deserve a separate discussion in this work.

${ }^{v}$ According to the literature the issue of low degrees of freedom and the risk of overdetermination characterizes comparative case study research in general and thus also the MD method. Nonetheless, equifinality and the risk of failing to reject a false null hypothesis is specific to the MD method and arguably more problematic. This is why the discussion of those two issues is kept separated in this section.

${ }^{v i}$ The null hypothesis in this case is that a relation is present between $\mathrm{X}_{0}$ and $\mathrm{Y}$. As show in Figure 1, no relationship is present thus showing that this hypothesis is false.

${ }^{v i i}$ Qualitative Comparative Analysis (QCA) (Ragin, 1987, Rihoux \& Ragin, 2009) represents a development of Mill's (1888) method of residues mentioned above. In this vein, it allows the researcher to overcome some shortcomings inherent to the traditional Millian comparative methods by accounting for complex causality as well as conjecturally sufficient and necessary causes.

viii Instead of epistemology some scholars (Elman \& Elman, 2003a) use the term metatheory to indicate a set of standards to assay theories, such as the ones provided by the Lakatosian philosophy of science.

${ }^{i x}$ For a thorough list of works which claim to use Lakatos's philosophy of science in International Relations see Elman and Elman (2003b, p.50-61)

${ }^{\mathrm{x}}$ Along with the attention on causal inference mentioned below another main achievement of the new methodology literature is the revamped attention on concept formation (Mahoney, 2010). By relying on Boolean algebra Goertz (2006) identifies two types of concept formation: the inclusive one associated with Sartori's (1970) work and the exclusive one associated with the philosopher Wittgenstein (1958). This work employs the former being more familiar to social science research.

${ }^{x i}$ As mentioned above, it should be noticed that from a Lakatosian view of research a research program is progressive if it is theoretically progressive, namely its explanatory power is higher than the previous theory $\mathrm{T}_{2}$ but only partially empirically progressive.

xii I acknowledge that Culpepper (2011) complements the covarational/configurational comparative case study research showed in this section with within case analysis, namely process tracing. Nonetheless, the latter arguably provides only additional leverage to the main research design which is based on comparative case study research.

xiii As stated above, cases are instances of a phenomenon which are spatially and temporally bounded according to the theory. In this vein, cases in this first part are instances of reforms of the market for corporate control which took place in in Germany and France in the 1990s.

${ }^{\text {xiv }}$ It should be noticed how both the research question and cases are different with respect to the previous part. Indeed, the research question in this second part is what determines business power in the reform of corporate governance in contemporary democracies and thus cases are represented by the reforms of corporate governance in Germany and France.
} 